\title{
Cooperative-blended learning using Moodle as an open source learning platform
}

\section{Dwi Sulisworo*, Sri Puji Agustin and Endang Sudarmiyati}

Physics Education Department, Ahmad Dahlan University,

Jl. Kapas No. 9,

Yogyakarta, Indonesia

Email: dwi.sulisworo@uad.ac.id

Email: sripujiagustin@gmail.com

Email: endangsdm123@gmail.com

*Corresponding author

\begin{abstract}
Some research in physics teaching in secondary schools shows that cooperative learning has the potential to improve student performance. Moodle is a learning management system that has open source platform modules that can be customised according to user's needs. The purpose of this study is to figure out the effectiveness of combination between the advantages of cooperative learning and e-learning as blended learning. The research objective is to see the effect of cooperative-blended learning strategy to the learning performance on physics in high school grade XII. This research is pre-testpost-test control group design using motivation as covariate. The dependent variable is a learning strategy. The independent variable is a learning achievement. The result showed that students who were taught using cooperative learning had higher learning achievement than those taught using face-to-face learning. Motivation can be used as predictor on cooperativeblended learning. Student who had higher motivation tend to get better learning achievement.
\end{abstract}

Keywords: cooperative learning; education; innovation; Jigsaw learning; learning achievement; learning strategy; mobile technology; motivation; online learning; online learning; physics education.

Reference to this paper should be made as follows: Sulisworo, D., Agustin, S.P. and Sudarmiyati, E. (2016) 'Cooperative-blended learning using Moodle as an open source learning platform', Int. J. Technology Enhanced Learning, Vol. 8, No. 2, pp.187-198.

Biographical notes: Dwi Sulisworo is a Senior Lecturer at the Graduate Program of Physics Education Department, Ahmad Dahlan University, Indonesia. His research interests are in the educational technology especially on learning strategy using information and communication technology. His current research related to the mobile technology for student learning improvement.

Sri Puji Agustin is alumnae of Physics Education for Master's degree. She has experience on high school education.

Endang Sudarmiyati is alumnae of Physics Education for Master Degree. She has a wide experience as a Physics teacher at high school level. 


\section{Introduction}

Results of research conducted by Sulisworo (2012) shows that the people of Indonesia nowadays are ready to use mobile technology either for social or technology necessity. But the results of the study (Sulisworo, 2013) showed that in school there was a paradox in which the student already had a good ICT literacy, but they were not facilitated by the school for the learning itself. It could be argued that the use of a smart phone as mobile learning tools in schools has controversy. On one hand, school prohibits it because it would interfere with the learning process in the classroom; on the other hand, the teacher saw much potential on using mobile technology (Sulisworo, 2013; Tal and Gross, 2014; Mohammad, Fayyoumi and AlShathry, 2015).

The positive thing is, in the last few years, there has been a significant change in the awareness of teachers in the use of ICT in learning. This phenomenon is a part of implications of wireless and mobile technologies rapid development in recent years (Alqahtani and Mohammad, 2015; Sulisworo, 2014). This technology is becoming cheaper with much higher capability, and the size is getting smaller. It makes educators or teachers realise that digital technology provides opportunities for a different form of learning, including the relationship between teachers and students, teachers and teachers, pupils and students, and students with teaching materials or competence (Babiker, 2015).

Based on the results of research in learning, many students are reluctant to learn in traditional ways. Consequently, it needs collaborative works to transform the weaknesses of mobile media and social platforms to be a boon for educational purposes. As educators, we need to seek new breakthroughs in the use of mobile devices in educational environments. Moreover, the results also showed that students prefer innovations in learning.

Some research in physics teaching in secondary schools shows that cooperative learning has the potential to improve student performance. It offers opportunities to create meaningful learning, interactive, inspiring, fun, challenging, and motivating learners to participate actively. Cooperative learning is a set of teaching strategies that are designed to teach teamwork and student-student interaction.

Moodle is a learning management system that has open sources platform modules that can be customised according to user needs. The research attempts to develop a Moodlebased to manage physics learning at high school. The purpose of this study is to figure out the effectiveness of combination between the advantages of cooperative learning and advantages of e-learning as blended learning. The research objective is to see the effect of blended learning strategy to the learning performance on physics in high school grade XII.

\section{Literature review}

\section{$2.1 \quad$ Blended learning}

Definition of blended learning has been growing along with the development of information and communication technology (Schober and Keller, 2012; Donnelly, 2010). Basically, the definition of blended learning leads on how to maximise the utilisation of the face-to-face learning and online learning (Delialioğlu, 2012; Akkoyunlu and Soylu, 2008). The implication of the adoption of blended learning on some institutions is the 
need to prepare a set of policy, planning, resources, and appropriate support (Poon, 2013). In many studies, it is stated that blended learning is regarded as useful, fun, supportive, flexible and motivating method for students (Akkoyunlu and Soylu, 2008; Delialioğlu, 2012).

When blended learning is seen only as an integration of system application, then this is not enough to create a successful learning environment (Schober and Keller, 2012). In order to create a positive learning environment, teachers must be able to encourage students to more participate (Donnelly, 2010) in their learning activities and must find a way that allows them to create more social interaction cooperatively (Liu, 2010; Delialioğlu, 2012). So it needs a learning plan that able to balance the face-to-face activity in the classroom and online learning environments (Akkoyunlu and Soylu, 2008; Donnelly, 2010).

In the situation of the current development of information and communication technology that has been dominated by tablets, smart phones, and touch screen devices for a variety of interests, blended learning becomes a new alternative for the improvement of student learning activities in schools. Integration of cooperative learning into online learning environment will create a new way of blended learning (Yen and Lee, 2011; Liu, 2010). Blended learning allows students to learn better (Akkoyunlu and Soylu, 2008; Yen and Lee, 2011).

\subsection{Cooperative learning and jigsaw}

\subsubsection{Cooperative learning}

Cooperative learning is an umbrella term for a set of teaching strategies that are designed to teach teamwork and interaction among students (Mehta and Kulshrestha, 2014; Gillies and Boyle, 2010). Cooperative learning objectives include at least three aspects, which are the result of academic learning, acceptance of diversity, and the development of social skills. This strategy is based on the theory of Vygotsky, which emphasises the social interaction as a mechanism to support cognitive development. Moreover, this method is also supported by learning theory and cognitive information processing theory of learning. The implementation of this learning theory will help students more easily proceed the information acquisition, because encoding process will be supported by the interactions in cooperative learning activities.

Cooperative learning instructional method has positive benefits when applied in the classroom. Some benefits include to teaching students to believe in the teacher, the ability to think, searching information from various sources and studying with other students, encouraging students to express ideas verbally and compare it with the other ideas and helping students learn to respect others (Ajaja and Eravwoke, 2010; Zakaria et al., 2013; Gillies and Boyle, 2010). The purpose of cooperative learning is different from other conventional group competition systems, in which individual success oriented to the failure of others. Cooperative learning with strong support for it and the fact that it makes sense for students' achievement and attitude towards studies is very viable option among other methods for teaching science in secondary schools (Ajaja and Eravwoke, 2010; Tsay and Brady, 2010; Mehta and Kulshrestha, 2014; Sulisworo and Suryani, 2014). Meanwhile, while the goal of cooperative learning is creating a situation where individual success is determined or influenced by the success of the group (Tsay and Brady, 2010; Zakaria et al., 2013; Sulisworo and Suryani, 2014). 
By definition, a cooperative learning model is a model of learning in practice emphasising the use of groups of students. The principle that should be upheld in connection with cooperative groups is that every student is in a group must have the ability levels of heterogeneous (high, medium, low) and if necessary they must come from different races, cultures, different ethnic groups and to consider gender equality. Cooperative learning model is based on cooperation while solving the problems of learning. This learning model is different from collaborative learning, and characterised by the presence of a learning task structure, the structure of the learning objectives and reward structures (Mehta and Kulshrestha, 2014; Davidson, Major and Michaelsen, 2014).

\subsubsection{Jigsaw Learning}

Jigsaw is one of the cooperative learning techniques. The purpose of this technique is to increase the students' sense of responsibility for their own learning and also learn from other members of their group (Zakaria et al., 2013; Tsay and Brady, 2010). They were asked to study the material that will be their responsibility, because they must also teach that material to other members of their group instead of himself. Jigsaw technique is a simulated setting of scientists of scientific community (Mehta and Kulshrestha, 2014). Using this technique, students will able to understand any phenomenon requiring research activity.

In Jigsaw learning, the dependence among students is very high. Basically, each student will be a member of two groups, namely

- the group home

- the expert group.

The home group was formed by members of the heterogeneous (Mehta and Kulshrestha, 2014). In this home group, they will share the task of the studied topic. After all members of the home group have obtained each task, they would leave the home group to form an expert group. The expert group is a group formed from members of the group who has the same task of the studied topic (based on their agreement in the home group). After studying the topic in their expert group, they will be back to their home groups and teach each topic that is their responsibility to the rest of the group in turn.

\section{Method}

\subsection{Research design}

This research was conducted for grade XII students of certain schools in Cirebon, a suburban area in West Java Province, Indonesia. This research is a quasi-experimental with pre-test-post-test control group design. The independent variable is a learning strategy. The control group was taught face-to-face learning in the classroom using direct lesson instruction. The treatment group was taught using blended learning. The steps of blended learning are described later. The study also included motivation as a predictor variable or covariate. The learning subject was physicsm, i.e., impulse and momentum. 
The number of participants was 30 and 32 for the control group and the treatment group, respectively.

\subsection{Course design}

The control group used face-to-face learning in the classroom using whiteboard and LCD presentation as well. The treatment group used blended learning. The learning management system used Moodle platform. The cooperative learning is jigsaw type, which combined to blended learning using e-learning. As a consequence, some of learning activities were in the classroom, and others were anywhere, anytime learning activities using student gadget. The steps of blended learning in this strategy are as follows:

- Step I. In the classroom, the teacher disseminate students about the teaching methods to be used and how to implement. Furthermore, teachers form home group and expert group for all students.

- Step II. The students work on their expert group. This is an online activity. Each expert group will study materials that have been determined. Each group will study different material. Furthermore, each group will discuss both synchronous and asynchronous online using chat or forum facilities that exist in e-learning system. Teachers also can monitor student activities through some features in the application. At this step, teacher needs to ensure the students' activity so that all members of the expert group would have learned and understood the teaching materials. The system has provided the exercises related to the material, to make sure they have a good learning progress. Learning resources have also been provided on the learning management system. Once this stage is completed, each student returns to his or her home group.

- $\quad$ Step III. It is conducted in the classroom. Each student explains the material corresponding to the expertise of each member to the home group. This step is very important because of the need of ensuring the transfer of knowledge from the students to others students for all learning material. Teacher plays an important role to encourage all students to be a tutor each other as a peer tutoring activity.

- $\quad$ Step IV. It is an online activity. Each student does exercises related to all the materials that have been learnt. Students work individually. At the end, teacher assesses the overall learning performance.

\subsection{Statistical analysis}

The differences among group means is analysed from the post-test result of control and treatment group. The independent variables and covariates are learning strategy and motivation, respectively. Then the statistical analysis is ANCOVA to evaluate whether means of learning achievement (post-test) of face-to-face learning is equal to one of cooperative-blended learning; and motivation as covariate, a nuisance variable which statistically controlling for the effect. 


\section{Result and discussion}

\subsection{Instrument validation}

\subsubsection{Motivation}

There are four factors included on the motivation variable, i.e., attention, relevance, selfesteem, and satisfactory. The items of each factor were divided into favourable and unfavourable statements. After several steps of validation and reliability test, the structure of the motivation instrument is shown in Table 1.

Table 1 Structure of learning motivation instrument

\begin{tabular}{lcccc}
\hline \multirow{2}{*}{ Criteria } & & \multicolumn{2}{c}{ Item number } & \\
\cline { 3 - 4 } Learning Motivation & Indicators & Favorable & Unfavorable & Total \\
\cline { 3 - 4 } & Attention & $1,3,4$ & 2,5 & 5 \\
& Relevance & $6,8,9$ & $7,10,11$ & 6 \\
& Self-esteem & $12,15,17$ & $13,14,16$ & 5 \\
& Satisfactory & $19,20,21$ & $18,22,23$ & 6 \\
Total & & 12 & 11 & 23 \\
\hline
\end{tabular}

\subsubsection{Knowledge Understanding}

The post-test or learning achievement is measured by a set of problem based on national competences standard of physics education for grade XII especially related to the subject matter as shown in Table 2. To find a good instrument to collect data, the researchers run a test on validity, reliability, level of difficulty, and power test. All calculations applied level of significance equal $5 \%$. The result was: 10 items were not valid and 30 items were valid. For the difficulty level, 6 items were easy, 27 items were moderate, and 8 were difficult. The power test found that 5 items have excellent power, 14 items were good, 10 items were moderate, and 11 items were not good power, respectively. The structure of this instrument is shown in Table 2.

Table 2 The structure of learning achievement instrument

\begin{tabular}{|c|c|c|c|c|c|}
\hline \multirow[b]{2}{*}{ Basic competences } & \multirow[b]{2}{*}{ Indicators } & \multicolumn{4}{|c|}{ Number of problems and cognitive level } \\
\hline & & $C 1$ & $C 2$ & $C 3$ & C4 \\
\hline \multirow[t]{2}{*}{$\begin{array}{l}\text { Understanding } \\
\text { impulse and } \\
\text { momentum } \\
\text { concepts, and } \\
\text { momentum } \\
\text { conservation } \\
\text { principle }\end{array}$} & $\begin{array}{l}\text { Ability to formulate a } \\
\text { certain problem of } \\
\text { impulse or } \\
\text { momentum to } \\
\text { mathematical } \\
\text { equation }\end{array}$ & 1,10 & $2,5,9$ & $3,6,8$ & 4,7 \\
\hline & $\begin{array}{l}\text { Abiltity to solve a } \\
\text { certain problem } \\
\text { related to momentum } \\
\text { conservation } \\
\text { principle using } \\
\text { mathematical } \\
\text { equation. }\end{array}$ & 16,19 & $\begin{array}{c}12,13,14 \\
18\end{array}$ & $11,15,20$ & 17 \\
\hline
\end{tabular}


Table 2 The structure of learning achievement instrument (continued)

\begin{tabular}{llcccc}
\hline \multirow{2}{*}{ Basic competences } & Indicators & \multicolumn{4}{c}{ Number of problems and cognitive level } \\
\cline { 2 - 5 } & $\begin{array}{l}\text { Ability to } \\
\text { demonstrate a }\end{array}$ & 23,24, & 22,29 & 21 & 25,27 \\
$\begin{array}{l}\text { physical phenomena } \\
\text { of impulse and } \\
\text { momentum concept }\end{array}$ & 26,28, & 30 & & & \\
Total & & & & \\
\hline
\end{tabular}

Before applied the ANCOVA, the normality and homogeneity the population sample was checked. The normality analysis used one-sample Kolmogorov-Smirnov test on significance level equal $5 \%$. Table 3 showed the result.

Table 3 One-sample Kolmogorov-Smirnov test

\begin{tabular}{llccc}
\hline & & Instrument & Pre-test & Post-test \\
\hline $\mathrm{N}$ & & 66 & 66 & 66 \\
Normal parameters $^{\mathrm{a}}$ & Mean & 62.5632 & 64.9495 & 75.2724 \\
& Standard deviation & 7.21923 & 7.14308 & 10.59387 \\
Most extreme differences & Absolute & 0.100 & 0.135 & 0.089 \\
& Positive & 0.100 & 0.135 & 0.089 \\
& Negative & -0.070 & -0.110 & -0.085 \\
Kolmogorov-Smirnov Z & & 0.812 & 1.094 & 0.721 \\
Asymptotic significance (two-tailed) & 0.524 & 0.183 & 0.676 \\
\hline
\end{tabular}

${ }^{a}$ Test distribution is normal.

From the row of asymptotic significance (two-tailed), it can be concluded that both group have normal distribution.

The Levene test was used to analyse the homogeneity of the samples as shown in Table 4.

Table 4 Test of homogeneity of variances

\begin{tabular}{lcccc}
\hline & Levene statistics & $d f 1$ & $d f 2$ & Significance \\
\hline Pre-test score & 0.420 & 1 & 64 & 0.519 \\
Post-test score & 0.816 & 1 & 64 & 0.370 \\
\hline
\end{tabular}

Df, degrees of freedom.

It can be observed that the group was from the same population, from the last column, and both groups were homogeneous. 


\subsection{Descriptive statistics}

Means and standard deviation of each group are shown in Table 5. It can be seen that the treatment group which applied cooperative-blended learning has higher mean of learning achievement (83.89) than the control group that applied face-to-face learning (68.09). On the contrary, the number of standard deviation, the control group is wider (7.58) than treatment group (6.44).

Table 5 Descriptive statistics

\begin{tabular}{lccc}
\hline \multicolumn{4}{c}{ Dependent variable: learning achievement } \\
\hline Learning strategy & Mean & Standard deviation & $N$ \\
\hline Treatment group & 83.8883 & 6.43662 & 30 \\
Control group & 68.0925 & 7.57932 & 36 \\
Total & 75.2724 & 10.59387 & 66 \\
\hline
\end{tabular}

\subsection{The result of ANCOVA}

The result of ANCOVA is shown in Table 6. The effect of the learning strategy and motivation can be analysed by considering the number of significance at the last column. Basic information is obtained to determine whether there is a linear relationship between the covariate (motivation variable) and the independent variable (learning achievement) to determine the effect of differences in treatment (learning strategy) to the learning achievement. From the aforementioned statistical result, the number of significance was very small for all variables at $5 \%$ of significance level.

Table 6 Tests of between-subjects effects

\begin{tabular}{|c|c|c|c|c|c|}
\hline \multicolumn{6}{|c|}{ Dependent variable: learning achievement } \\
\hline Source & Type III sum of Squares & Degrees of freedom & Mean square & $F$ & Significance \\
\hline $\begin{array}{l}\text { Corrected } \\
\text { model }\end{array}$ & $7290.632^{a}$ & 2 & 3645.316 & $5.320 \mathrm{E} 4$ & 0.000 \\
\hline Intercept & 7.393 & 1 & 7.393 & 107.892 & 0.000 \\
\hline Motivation & 3207.768 & 1 & 3207.768 & 4.681E4 & 0.000 \\
\hline Strategy & 5.757 & 1 & 5.757 & 84.022 & 0.000 \\
\hline Error & 4.317 & 63 & 0.069 & & \\
\hline Total & 381246.847 & 66 & & & \\
\hline $\begin{array}{l}\text { Corrected } \\
\text { total }\end{array}$ & 7294.949 & 65 & & & \\
\hline
\end{tabular}

${ }^{a} \mathrm{R}$ squared $=0.999$ (Adjusted $\mathrm{R}$ squared $=0.999$ )

Basic information is obtained to determine whether there is a linear relationship between the covariate (motivation variable) and the independent variable (learning achievement), and to determine the effect of differences in treatment (learning strategy) to the learning achievement. The aforementioned statistical result showed that the number of significance was very small for all variables at $5 \%$ of significance level. 
The first conclusion is that there was a linear relationship between learning motivation and learning achievement. It means that learning achievement as students learning performance can be predicted from their motivation. There a tendency that students whose higher learning motivation will get higher learning achievement.

The second is that the learning strategy affected the learning achievement. The value of learning achievement is significantly different between students who were taught faceto-face and of cooperative-blended learning. Similarly, it can be said that cooperativeblended learning will tend to give better learning achievement than face-to-face learning.

The third is that both motivation and learning strategies simultaneously affected the learning achievement.

\subsection{Implications}

From the statistical analysis, we could see that motivation and learning strategies affect student learning outcomes either individually or by groups. Motivation can also be used as predictor of student learning achievement. But, the more important is the explanation on how it could work.

From the comparison between pre-test and post-test results, it can display the increasing achievement of learning. Results from the pre-test showed that students in the face-to-face classroom have average learning achievement (65.09) slightly higher than those in the cooperative-blended learning (64.78). While the post-test were 68.50 and 83.89 for the cooperative-blended learning and face-to-face, respectively, as shown in Figure 1.

Figure 1 Learning achievement gain (see online version for colours)

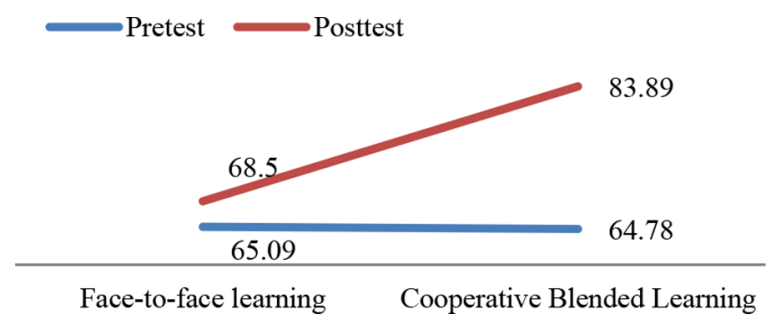

From Figure 1, it can be seen that the gain of cooperative-blended learning is higher than face-to-face learning. Some studies showed that students feel comfortable when working using their gadgets. Activities that allow students to learn and to interact online also tend to help increase students performance. It is obviously captured in some students' comments during the discussion in the classroom after online activities. The pleasure increased their interest in learning and also became a positive external factor for motivation. The indicator was the number of conversation among students in both the forum and chat activities. In addition, students who lack confidence and tend to be reserved when meeting physically-turned out in online activities. The students became more active and confident. It can be said that there was an increase on students' motivation to learn physics. In addition, the interest was also increased.

Students also appreciated the availability of the e-materials in various forms of media such as pictures, video, animation, simulation, links to a variety of learning resources. Availability of media made students easier to repeat the material that considered difficult. Chats and forums features were also very helpful to ask the difficulties 
encountered. Students could help each other more intensive and there was no pressure to do that. Some suggestions from the students were the needs for more practical questions. The limitation of the number of exercise tend to bring less motivation for student to do this exercise because students became familiar with the answer of the question.

The increase in learning outcomes showed that the learning of physics on the subject of impulse and momentum using cooperative strategies blended learning can enhance students' understanding of the material. During learning, students can think more freely, so as to foster interest and motivation of students in acquiring the subject matter. In the end, these conditions can improve student learning achievement.

Observations during the learning activities, the interest of students in the new learning strategy made them eager to visit an e-learning. Chat and interactive menus made students feel interested in using these media. Students' activity is an influential factor that determines the success of students learning. It has been stated by Sulisworo (2012) that the quality of online learning interaction is very important to the success of learning.

The availability to learn anywhere and anytime makes students to feel more comfortable because they do not always feel supervised by a teacher. In this interaction, the teacher's role is as a facilitator to ensure learning activity goes well for achieving determined competence.

At the beginning of the learning, socialising the learning strategy in the classroom is also an important factor. The ability of teachers to ensure the achievement of competence and explanation of the importance of learning strategies will determine the continuity of learning. It should be considered that sometimes misbehaviour still appears in the learning process, e.g., students post something irrelevant to the topic of learning. In such cases, the ability of teachers who position themselves as the friend in learning will be able to manage the situation.

The high ICT literacy level of students become one of the factors for the success of students' independent online learning. Teachers must combine high literacy and the students' interest to promote online learning strategies, thus the students become more enthusiastic. Those things are the reasons why the students' understanding who were taught using cooperative-blended learning is higher than of face-to-face classroom learning.

E-learning provides an opportunity for learners to take control over the success of each study, meaning that learners are given the freedom to decide when to start, when it will finish, and what part of the material to learn first to be expert when in expert group. Students will generally start from the interesting topics first, or could pass only the part that they mastered. If they find difficulties to understand some parts of, they could repeat again until they understand or discussed with other group members. In the case of cooperative-blended learning, learning independently is more effective than the other way of learning, which obliges to them to study with the established order.

\section{Summary}

Learning strategy has significant effect to student learning achievement. Student who were taught using cooperative-blended learning got higher learning achievement than student who taught using face-to-face learning. Cooperative-blended learning has a potential opportunity as a learning strategy on physics teaching and learning. Using this 
strategy, students learning achievement can be improved, for examples due to the increasing learning interest, self-esteem, and various learning resources.

Students motivation can be used as a predictor to predict the students' learning achievement on cooperative-blended learning strategy. The higher motivation of the student tends to get higher learning achievement. The improvement of students' selfesteem when they used cooperative-blended learning is a positive aspect to be taken for learning.

Beside these opportunities, there are some aspects to be considered. They are a shifting role of teacher from the knowledge authority to learning facilitator, and the ability of teachers to maintain students' discussion in their learning. In addition, cooperative-blended learning generally is a strategy a teacher can use to take advantage of both online learning and face-to-face learning to improve student's learning in this mobile technology era.

\section{References}

Ajaja, O.P. and Eravwoke, O.U. (2010) 'Effects of cooperative learning strategy on junior secondary school students achievement in integrated science', Electronic Journal of Science Education, Vol. 14, No. 1, pp.1-18.

Akkoyunlu, B. and Soylu, M.Y. (2008) 'A study of student's perceptions in a blended learning environment based on different learning styles', Educational Technology \& Society, Vol. 11, No. 1, pp.183-193.

Alqahtani, M. and Mohammad, H. (2015) 'Mobile applications' impact on student performance and satisfaction', The Turkish Online Journal of Educational Technology, Vol. 14, No. 4, pp.102-112.

Babiker, M.E. (2015) 'For effective use of multimedia in education, teachers must develop their own educational multimedia applications', The Turkish Online Journal of Educational Technology, Vol. 14, No. 4, pp.62-68.

Davidson, N., Major, C.H. and Michaelsen, L.K. (2014) 'Small-group learning in higher education-cooperative, collaborative, problem-based, and team-based learning: an introduction by the guest editors', Journal on Excellence in College Teaching, Vol. 25, Nos. 3 and 4, pp.1-6.

Delialioğlu, Ö. (2012) 'Student engagement in blended learning environments with lecture-based and problem-based instructional approaches', Educational Technology \& Society, Vol. 15, No. 3, pp.310-322.

Donnelly, R. (2010) 'Harmonizing technology with interaftion in blended problem-based learning', Computers and Education, Vol. 54, No. 2, pp.350-359.

Gillies, R.M. and Boyle, M. (2010) 'Teachers' reflections on cooperative learning: issues of implementation', Teaching and Teacher Education, Vol. 26, pp.933-940.

Liu, S.-H. (2010) 'Factors related to pedagogical beliefs of teachers and technology integration', Computers \& Education, Vol. 56, pp.1012-1022.

Mehta, S. and Kulshrestha, A.K. (2014) 'Implementation of cooperative learning in science: a developmental-cum-experimental study’, Education Research International, Vol. 2014, pp.1-7.

Mohammad, H., Fayyoumi, A. and AlShathry, O. (2015) 'Do we have to prohibit the use of mobile phones in classrooms?', International Journal of Interactive Mobile Technology, Vol. 9, No. 2, pp.54-57.

Poon, J. (2013) 'Blended learning: an institutional approach for enhancing students' learning experiences', MERLOT Journal of Online Learning and Teaching, Vol. 9, No. 2, pp.271-288. 
Schober, A. and Keller, L. (2012) 'Impact factors for learner motivation in blended learning environments', International Journal of Emerging Technology, Vol. 7, Special Issue 2, FNMA, 37-41.

Sulisworo, D. (2012) 'The social readiness to implement mobile learning in Indonesia', International Conference on Culture, Communication and Multimedia Technology, pp.387-391. Yogyakarta: UAD.

Sulisworo, D. (2013) 'The paradox on IT literacy and science's learning achievement in secondary school', International Journal of Evaluation and Research in Education, Vol. 2, No. 4, pp.149-152.

Sulisworo, D. (2014) 'Conceptual model identification of personal learning environment', Innovation and Development in Teaching and Learning, UMM, Perak, Malaysia, pp.37-41.

Sulisworo, D. and Suryani, F. (2014) 'The effect of cooperative learning, motivation and information technology literacy to achievement', International Journal of Learning \& Development, Vol. 4, No. 2, pp.58-64.

Tal, H.M. and Gross, M. (2014) 'Teaching sustainability via smartphone-enhanced experiential learning in a botanical garden', International Journal of Interactive Mobile Technology, Vol. 8, No. 1, pp.10-15.

Tsay, M. and Brady, M. (2010) 'A case study of cooperative learning and communication pedagogy: does working in teams make a difference?', Journal of the Scholarship of Teaching and Learning, Vol. 10, No. 2, pp.78-89.

Yen, J.-C. and Lee, C.-Y. (2011) 'Exploring problem solving patterns and their impact on learning achievement in a blended learning environment', Computers \& Education, Vol. 56, pp.138-145.

Zakaria, E., Solfitri, T., Daud, Y. and Abidin, Z.Z. (2013) 'Effect of cooperative learning on secondary school students' mathematics achievement', Creative Education, Vol. 4, No. 2, pp.98-100. 